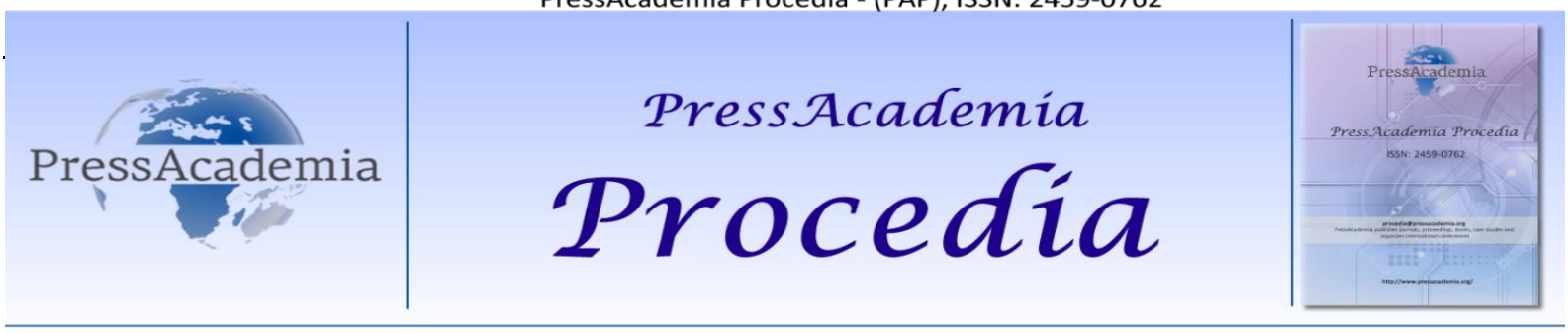

Global Business Research Congress (GBRC), May 24-25, 2017, Istanbul, Turkey.

\title{
THE EFFECT OF INTERPERSONAL INTELLIGENCE LEVELS ON THE ENTREPRENEURSHIP POTENTIAL: A RESEARCH ON UNIVERSITY STUDENTS
}

\author{
DOI: 10.17261/Pressacademia.2017.667 \\ PAP- GBRC-V.3-2017(94)-p.867-874

\section{Vasfi Kahya ${ }^{1}$, Esin Ceylan ${ }^{2}$} \\ Dumlupınar University, Kütahya, Turkey. vasfi.kahya@dpu.edu.tr \\ Selçuk University, Konya, Turkey. esinceylan@selcuk.edu.tr
}

\author{
To cite this document \\ students PressAcademia Procedia (PAP), V.3, p.867-874. \\ Permemant link to this document: $\mathrm{http}: / /$ doi.org/10.17261/Pressacademia.2017.667 \\ Copyright: Published by PressAcademia and limited licenced re-use rights only.
}

Kahya, V. and E. Ceylan, (2017). The effect of interpersonal intelligence levels on the entrepreneurship potential: a research on university

\begin{abstract}
The aim of this study is to investigate the importance, level and direction of the possible relationship between the entrepreneurship potential of university students and their interpersonal intelligence levels. Tromso Interpersonal Intelligence Scale (TIIS) improved by Silvera, Martinussen and Dahl (2001) has been used to determine the levels of interpersonal intelligence. The questions for determining the entrepreneurship potential have been made up by utilizing the thesises translated by Ören and Biçkes (2011) and prepared by Central of Rural Entrepreneurship which is an entrepreneurship center. Personal information form prepared by the researchers has been used as a data collection tool in researching. The participants of the research are university students continuing their education in $\mathrm{Kütahya.}$ Correlation and regression analysis have been used for the analysis of data. In the outcome of the research, it is showed that social knowledge process, social skills and social awareness which are interpersonal intelligence levels is positive effects on the entrepreneurship potential.
\end{abstract}

Keywords: Interpersonal Intelligence, entrepreneurship, entrepreneurship potential.

JEL Codes: M11, L2, L26

\section{SOSYAL ZEKÂ DÜZEYLERININ GIRIŞiMciLiK POTANSIYELI ÜZERINDEKI ETKISI: ÜNIVERSITE ÖĞRENCILERI ÜZERINE BIR ARAŞTIRMA}

\section{ÖZET}

Bu araştırmanın amacı üniversite öğrencilerinin girişimcilik potansiyeli ile sosyal zekâ düzeyleri arasında olası ilişkilerin önemini, düzeyini ve yönünü incelemektir. Sosyal zekâ düzeylerinin belirlenmesi için Silvera, Martinussen ve Dahl (2001) tarafından geliştirilen Tromso Sosyal Zekâ Ölçeği (TSZÖ) kullanılmışır. Girişimcilik potansiyelini belirlemeye yönelik sorular ise Ören ve Biçkes (2011) tarafından tercüme edilen ve bir girişimcilik merkezi olan Central of Rural Entreprenuership tarafından hazırlanan önermelerden yararlanılarak oluşturulmuştur. Araştırmacılar tarafından hazırlanan kişisel bilgi formu araştırmada veri toplama aracı olarak kullanılmıştır. Araştırmanın katılımcıları Kütahya'da öğrenimlerine devam eden üniversite öğrencilerinden oluşmaktadır. Verilerin analizi için korelasyon ve regresyon analizi kullanılmaktadır. Araştırma sonucunda sosyal zekâ düzeyleri olan sosyal bilgi süreci, sosyal beceriler ve sosyal farkındalığın girişimcilik potansiyeline pozitif etki yaptığı görülmektedir.

Anahtar Kelimeler: Sosyal zeka, girişimcilik, girişimcilik potansiyeli.

JEL Kodları: M11, L2, L26 


\section{GíRiş}

İnsanların bilgiyi öğrenme, toplumsal hayatta meydana gelen olayları algılama ve yorumlama yetenekleri birbirlerinden değişiklik göstermektedir. Bu değişikliklerin temel sebebi bireylerin sahip oldukları çeşitli zekâ türleri ile açıklanabilmektedir.

Zekânın tanımını ilk kez Binet yapmıştır. Bu tanıma göre zekâ,"dış dünyanın algılanması, algıların bellekte yerleştirilmesi ve bu içerik üzerinde düşünülmesi sürecidir" (Öner, 1997: 28).

Zekâ eski (geleneksel) anlayışa göre; doğuştan kazanılır, sabittir ve bu nedenle asla değiştirilemez. Niceliksel olarak ölçülebilir ve tek bir sayıya indirgenebilir. Gerçek hayattan soyutlanarak (yani, belli zekâ testleri ile) ölçülür. Öğrencileri belli seviyelere göre sınıflandırmak ve onların gelecekteki başarılarını tahmin etmek için kullanılır (Saban, 2004). 1983 yılında Howard Gardner'ın "Frames of Mind: The Theory of Multiple Intelligences” (Zihnin Çerçeveleri: Çoklu Zekâ Kuramı) adlı kitabını yazmasıyla zekânın geleneksel yaklaşımdan çıkarak çoklu bir boyut kazandığı söylenebilir.

Gardner (1983) geleneksel zekâ anlayışının aksine bireyin genetik özelliği ile sahip olduğu zekâsının zamanla gelişebilir olduğunu, sayısal yöntemlerle hesaplanamayacağını, gerçek hayat şartlarından soyutlanamayacağını ve bireylerin çeşitli zekâ alanlarından hepsine sahip olduğunu ifade emektedir (Saban, 2004).

Yeni anlayışa göre zekâ; bir bireyin genetiksel olarak kalıtımla birlikte getirdiği zekâ kapasitesi iyileştirilebilir, geliştirilebilir ve değiştirilebilir. Herhangi bir performansta, üründe veya problem çözme sürecinde sergilendiğinden sayısal olarak hesaplanamaz. Çoğuldur ve çeşitli yollarla sergilenebilir. Zekâ, gerçek hayat durumlarından veya koşullarından soyutlanamaz. Öğrencilerin sahip oldukları gizli güçleri veya doğal potansiyellerini anlamak ve onların başarmak için uygulayabilecekleri farklı yolları keşfetmek için kullanılmaktadır (Saban, 2004).

Gardner'in Çoklu Zeka Kuramı, geleneksel IQ (Intelligent Quotient) anlayışını yok ederek bireylere değer veren bir zekâ anlayışını ortaya çıkarmıştı (Baş, 2011:16). Çoklu zeka teorisi içerisinde yer alan sosyal zeka, "kişilerarası durumlarda kişinin kendisi dahil, insanların duygu, düşünce ve davranışlarını anlama ve o anlayışa uygun davranma yeteneğidir" (Marlowe,1986).

Sosyal zeka seviyesi yüksek olan bireyler çalışma yaşamında sosyal zekâ seviyesi düşük olan bireylere göre daha başarılıdır (Doğan ve Demiral, 2007). Yapılan çalışmalara bağlı olarak bireylerin iş ve sosyal sosyal hayatındaki başarısında IQ (Intelligent Quotien) 'nun sadece \%20 oranında etkilediği sonucuna varılmıştır (Goleman, 2014:62). Bireyler sahip oldukları sosyal zekâ seviyesine bağlı olarak girişimci kişiliklerinin gelişmesini de etkiyebilmektedirler. Bu bağlamda sosyal zekâ ve girişimcilik ilişkisi yeniliklere açık olma, inovatif düşünebilme ve risk alabilme yeteneklerinin gelişmiş olmasıyla da ilgili olmaktadır.

\section{LITERATÜR INCELEMESI}

\section{SOSYAL ZEKÂ}

Gardner çocuklar ve beyin tahribatına uğramış yetişkin bireyler üzerine yapığı çalışmalar esnasında bazı soruları cevaplamak için yola çıkmış ve bunun sonucunda 1983 yılında "Frames of Mind: The Theory of Multiple Intelligences (Zihnin Çerçeveleri: Çoklu Zekâ Kuramı)" eserini ortaya çıkarmıştır. Her bireyin birbirinden farklı yeteneklere sahip olduğunu ve bunun herkes tarafından bilindiği için Gardner eserinde daha çarpıcı ve dikkat çekici bir kavram olan "zekâ"yı kullanmıştır. Bilinçli olarak birbirinden tamamen bağımsız olan Müzik Zekâ'sından, Kendini Tanıma ve Anlama Zekâ'sına kadar uzanan bilinmeyen sayıda zekâyı vurgulamak için "çoklu zekâ" kavramını ortaya atmıştır (Altan, 2011:54). Gardner (1983), Çoklu Zekâ Teorisi'nde zekânın iki değil en az yedi boyutunun olduğunu savunmuştur (Ayaydın, 2004:19). Daha sonra Checkley'in Gardner ile yapmış olduğu bir görüşmede, Gardner sekizinci bir zekâ alanının varlığından söz etmiş ve 1999'da yayımladığı "Intelligence Reframed: Multiple Intelligences for the 21.Century" adlı eserinde bu yeni zekâ kavramını da ele almıştır (Saban,2001:6). Bu sekiz zekâ alanı aşağıdaki şekilde sıralanabilir (Gardner; 1993a, 1993b, 1999): Sözel/Dilsel Zekâ, Mantıksal/Matematiksel Zekâ, Görsel/Uzamsal Zekâ, Bedensel/Kinestetik Zekâ, Müziksel/Ritmik Zekâ, Sosyal/Bireyler arası Zekâ, Kişisel/Özedönük Zekâ, Doğa/Doğacı Zekâ'dır.

Çoklu zekâ kuramının dayandığı temel odak noktaları şunlardır (Armstrong:1994).

1. Her birey, farklı zekâ alanlarının tümüne sahiptir ve bu zekâ alanları değişik seviyelerde bulunabilir.

2. Her birey, farklı zekâ alanlarından her birini yeterli bir seviyede geliştirebilir.

3. Farklı zekâ alanları genellikle bir arada ve karmaşık bir yapıda çalışılar.

4. Bir bireyin her alanda zeki olabilmesinin pek çok yolu vardır.

1983 yılında Gardner tarafından ortaya atılan çoklu zeka teorisi, zekanın sadece bir boyuttan oluşmayıp bireylerin farklı derecelere sahip çeşitli zekâlara sahip olduğu öne sürülmüştür (Vural, 2004:232 ve Çakır, 2004 Akt: Yılmaz, 2008: 240). 
Gardner, herhangi bir özelliğin zekâ olabilmesi için sembollerin olması, kültürün değer vermesi, mal veya hizmet üretmeye aracı olması ve problem çözebilmesi gerektiğini ileri sürmektedir (Bellanca, 1997). Gardner'e göre zekâ, "bir ya da birden fazla kültürde değer bulan bir ürün ortaya koyma kapasitesi; gerçek hayatta karşılaştığı problemlere etkili ve verimli çözümler üretebilme becerisi; çözüme kavuşturulması gereken yeni ve karmaşık yapılı problemleri keşfetme yeteneğidir" (Gardner 1993b: 15).

Illk olarak sosyal zekâ kavramı 1920 yılında Thorndike'nin zekâyı "sosyal, mekanik ve soyut" olarak tanımlamasıyla ortaya çıkmıştır (Doğan ve Çetin, 2009:693). Ancak sosyal zekâ kavramı Gardner (1983)'ın çoklu zekâ kuramını ortaya atıncaya kadar var olan zeka teorileri arasında yerini bulmakta sorun yaşamıştır (Crowne, 2007).

Sosyal zekâ, bireylerin bir grup içerisinde çalışabilmesi, başka bireylerle sözlü veya sözsüz iletişim kurma yeteneğini kapsamaktadır. Bireyler arasında meydana gelen ilgi farklılıkları da sosyal zekâ alanını açıklamaktadır (Gardner, 1993b:22).

Torndike (1920) sosyal zekâyı; "(i) insanları anlama ve idare etme yeteneği, (ii) insan ilişkilerinde ustaca davranma yeteneği" olarak tanımlamıştır (Doğan ve Çetin, 2009:693). Silvera vd., ise sosyal zekâyı; "diğer insanları ve her bir değişik sosyal duruma nasıl tepki vereceklerini anlama yeteneği" olarak tanımlayarak sosyal zekâyı üç boyut belirlemişlerdir. Bu üç boyutu ölçen Tromso Sosyal Zekâ ölçeğini geliştirmişlerdir. Bu boyutlar ise şunlardır (Silvera vd., 2001):

(i) Sosyal Bilgi İ̧̧leme: Bireyin kendisinin ve diğer bireylerin duygu ve düşüncelerini anlaması, ilişkilerde başkalarının istek ve beklentilerini anlayabilmesi gibi yeterlilikleri içermektedir.

(ii) Sosyal Beceriler: Sosyal zekânın performans boyutuyla ilgilidir. Sosyal beceri düzeyi yüksek birey sosyal ortamlara rahatlıkla bulunabilir, diğer insanlarla anlaşmakta zorluk çekmez ve sosyal ortamlara kolaylıkla uyum sağlar.

(iii) Sosyal Farkındalık: Bireyin içinde bulunduğu sosyal ortama ve şartlara uygun davranma yeteneğini açıklamaktadır. Sosyal farkındalı̆̆ yüksek olan bireyler içinde bulunduğu sosyal ortama uygun davranışlar göstermede, bu davranışlara uygun tepkiler vermede ve geri bildirimde bulunma konusunda oldukça başarılıdır.

\section{GiRișiMciLik}

Girişimci kavramı ilk kez 1755 yılında Cantillon tarafından "kâr elde etmek amacıyla işini organize eden ve işin riskini üstlenen kişi” olarak tanımlanmıştır (Kozak ve Yılmaz, 2010:85). Girişimcilik alanında yenilikçilik kavramını ele alan ilk kişi ise Schumpeter olmuştur. Schumpeter (1961)'e göre girişimci, "yeniliği ekonomik sistemde var olan sosyal ve kurumsal engellerin üstesinden gelmek için mevcut durumu zorlayarak gerçekleştiren kişidir" (Döm, 2006:3-4).

20. yy'da ortaya atılan girişimcilik teorisine göre, girişimci risk alarak "yenilik" yapan kişidir (Sabuncuoğlu ve Tokol, 2013:29). Bilgi çağı olarak da adlandırılan 21. yy'da insan sosyal ve ekonomik yapının merkezinde olup bilgiyi üreten, kullanan ve yöneten durumundadır. Bilgi toplumunda girişimcisinin bilgiye ve bilgiyi yönetebilme yeteneğine ihtiyacı vardır (Sabuncuoğlu ve Tokol, 2013:34). Buna bağlı kalınarak girişimci, üretim faktörlerini (emek, sermaye, doğal kaynaklar, bilgi) kullanarak insan ihtiyaçlarını karşılamak amacıyla mal ve hizmet üretmek için birleştiren, kâr elde etme amacı güden ve riske katlanan kişidir (Tutar, 2013: 34).

Girişimcilik üzerine farklı tanımlar yapılsa da genel olarak yenilikçi düşünme, fırsatları görebilme ve değerlendirebilme, yeni ürün üretmek vb., unsurlar sayılabilir (Bozkurt vd., 2012:232). Bunlarla birlikte girişimcilerde problem çözme, güvenilirlik, risk alma, inisiyatif alma, azimli olma, kararlı olma, gerçeklik, motivasyon gibi özelliklerin de bulunması gerekmektedir (Döm, 2006: 5).

İdeal girişimci tipini tanımlamada sosyal bilimciler tam bir uzlaşma sağlayamamışlardır. Ancak McClelland'a (1961) göre, sosyal bilimcilerin üzerinde birleştikleri nitelikler şunlardır: : (a) belli konularda yetenekli olma ve kâr için mantıki riskleri göze alabilme; (b) enerjik bir kişilik; (c) kişisel sorumluluk duygusuna sahip olma; (d) verdiği kararların başarısını para ile ölçebilme yeteneği; (e) gelecek hakkında sağlam tahminler yapabilme; (f) örgütleme yeteneği; (g) ve nihayet kendilerine prestij sağlama ve risk göze almaları karşılığı olarak kişisel yarar elde etme (Şaylan, 1974:58).

\section{SOSYAL ZEKÂ iLE GIRIŞiMCiLIK POTANSIYELI ARASINDAKi iLișKi}

Girişimcilik sosyo-ekonomik faktörlerin bir araya gelmesiyle oluşan bir olgudur. Bu faktörler; girişimcilik faaliyetini başlatıp devam ettiren bireye ait özellikler bakımından girişimci birey, girişimci bireyin potansiyelini ortaya çıkaran, kişilik yapısını oluşturan ve girişimcilik olgusunu belirleyen sosyo-kültürel/politik ve diğer dışsal/çevresel koşullar olarak ifade edilmektedir (ilhan, 2003: 61). Girişimcilik potansiyeli ise bireyin çabası, enerjisi, ekonomik gücü, bilgi ve tecrübe birikimine bağlı olan girişimcinin başarısı ile ilgilidir. Bunun yanında başarı bireyin genel çevresi ile ilgili de olsa girişimcilik potansiyeli önemli ölçüde girişimcinin sahip olduğu bireysel özelliklere bağııdır (Hisrich ve Peters, 2002:32-33). Girişimcilik bireyin sahip olduğu değerler sistemi ile birlikte iş bilgisini ve becerisini kullanma, iş geliştirme sürecinde gerekli olan ihtiyaçları karşılama ve sorunlar için yaratıcı ve yenilikçi çözüm kaynaklarını elde etme yeteneği ile de ilgilidir (Özgener, 2003:100). 
Girişimci bireylerin başarıları sahip oldukları zihinsel kapasiteleri ile ilgili olmaktadır. Bu kapasiteler çoklu zekâ teorileri ile değerlendirildiğinde sosyal zekâ da iş yaşamında etkili olmaktadır. Sosyal zekâ seviyesi yüksek olan bireylerin iletişim becerileri yüksektir. İş hayatında sosyal zekâsı yüksek olan bireylerin iş başarısının artmasına sebep olabilir.

Sosyal zeka ile girişimcilik potansiyeli üzerine yapılan çalışmalar incelendiğinde; Marecki (2014), sosyal zekanın girişimci liderler için önemi üzerine yapılan çalışma da girişimci liderlerin sosyal zekalarının motivasyon üzerine etkisi olduğu sonucuna varılmıştır. Parlak (2013), girişimci kişilik özelliklerine sahip olmak ile içsel ve sosyal zekâlar arasındaki ilişkiyi incelemiş ve pozitif yönlü ilişki bulunmuştur. Demirel vd. (2011), çoklu zekâ alanlarının girişimcilik davranışına etkisi üzerine yapmış oldukları çalışmada çoklu zekâya dayalı yeteneklerin girişimcilik düşünceleri üzerine olumlu etkisinin olduğu sonucuna varılmıştır.

\section{VERI VE YÖNTEM}

\section{Araştırmanın Amacı, Önemi ve Yöntemi}

Araştırmada, genel sosyal zekâ düzeyi ve sosyal zekâ alt boyutlarına sahip kişilerin girişimcilik potansiyelleri arasındaki ilişkinin incelenmesi amaçlanmaktadır. Sosyal zekâsı yüksek her bireyin girişimcilik potansiyelinin de yüksek olup olmadığı ve varsa etkisi, ayrıca hangi alt boyutun bu durumu daha çok etkilediği çalışmamızın ana konusunu oluşturmaktadır. Yapılan literatür taramalarında çoklu zekâ kuramı ile ilgili çalışmaların olduğunu farklı değişkenlerle birlikte sosyal zekâ boyutunun da ele alındığı görülmektedir (Parlak, 2013; Demirel vd. 2011). Fakat sosyal zekâyı alt boyutları ile birlikte ele alan herhangi bir çalışmaya rastlanmamış olması çalışmayı değerli hale getirmiştir. Bunun yanında girişimcilik potansiyelini ele alan çok sayıda çalışma mevcuttur. Bu çalışmaların ışı̆̆ında girişimcilik potansiyelini etkileyen önermeler mevcuttur. Bu çalışmada ise sosyal zekâ alt boyutlarının (sosyal farkındalık, sosyal bilgi süreci, sosyal beceri) hangilerinin girişimcilik potansiyeline etki edeceğini açıklıyor olması, girişimcilik için açıklanamayan kısmına ışık tutacağı yönünde fikir oluşturmaktadır. Bu açıdan çalışmanın literatüre olumlu katkı sağlayacağı yönünde kanaati güçlendirmektedir. Araştırmada nicel yöntem kullanılmıştır. Veri toplama aracı olarak anket tekniğinden faydalanılmıştır. Yapılan literatür taramaları sonucunda üç bölümlü bir anket oluşturulmuştur. Anket formu tümüyle kapalı uçlu sorulardan oluşmaktadır. Katılımcılara cevapların beş noktalı likert ölçeği üzerinden belirtilmeleri istenmiştir.

Birinci bölümde demografik değişkenler, ikinci bölümde sosyal zekâ boyutlarını ele alan sorular ve üçüncü bölümde ise girişimcilik potansiyelini ölçen sorulara yer verilmiştir. Sosyal zekâ boyutlarını ele almak için Tromso Sosyal Zekâ Ölçeği (TSZÖ) (Tromso Social Intelligence Scale) olarak bilinen ve Silvera ve arkadaşları (2001) tarafından geliştirilen sorulardan faydalanılmıştır. Ölçeğin Türkçe uyarlaması Doğan ve Çetin (2009) tarafından yapılmış ve bu haliyle kullanılmıştır. Ölçekte sosyal bilgi süreci, sosyal farkındalık ve sosyal beceri olmak üzere üç alt boyutta 21 sorudan oluşmaktadır. Girişimcilik potansiyelini belirlemeye yönelik sorular ise Ören ve Biçkes (2011) tarafından tercüme edilen ve bir girişimcilik merkezi olan Central of Rural Entreprenuership tarafından hazırlanan önermelerden yararlanılarak oluşturulmuştur. Çalışmanın güvenilirliği için yapılan analiz neticesinde cronbach alpha değeri 0,820 olarak bulunmuştur. Güvenilirlik katsayısının 0,70'den daha yüksek oluşu sosyal zekâ ve girişimcilik potansiyeli ölçeklerinin oldukça güvenilir olarak nitelemek için yeterli bir değerdir. Bulguların değerlendirilmesi için korelasyon ve regresyon testlerinden yararlanılmıştır.

\section{Araştırmanın Hipotezleri}

Yukarıda ifade edilen bilgiler ışığında oluşturulan hipotezler aşağıdaki gibidir;

H1: Sosyal zekâ ile girişimcilik potansiyeli arasında anlamlı ve pozitif bir ilişki vardır.

H2: Sosyal zekâ alt boyutarı ile girişimcilik potansiyeli arasında anlamlı ve pozitif bir ilişki vardır.

\section{Araştırmanın Kapsamı, Sınırıııkları}

Araştırmanın evreni Dumlupınar Üniversitesine bağlı meslek yüksekokullarında okuyan öğrenciler oluşturmaktadır. Öğrencilere 320 adet anket dağıtılmış ve eş zamanlı olarak doldurmaları istenmiştir. 305 adet anket değerlendirmeye tabi tutulmuş geriye kalan 15 adet anketin ise tutarsızlığı sebebi ile değerlendirmeye alınmamıştır. 320 adet anket formu 2. sınıf öğrencilere bölümleri dikkate alınarak dağıtılmıştır.

Araştırmanın en önemli sınırlılığı ise tek bir üniversiteye bağlı meslek yüksekokullarında yapılmış olması ve başka bir üniversitede uygulanmamış olmasıdır.

\section{BULGULAR VE TARTIŞMA}

Araştırma Dumlupınar Üniversitesine bağlı meslek yüksekokullarında okuyan 320 öğrenci üzerinde uygulanmıştır. Verilerin analizi sırasında oluşabilecek uç değerlerin arındırılması sağlanmış aynı zamanda kayıp değerler yerine ortalama değerlerin atanması yapılmıştır. Bu düzeltmelerden sonra analize tabi olacak anket sayısı 305'e düşmüş bunlardan 162'si kız öğrenciler, 
143'ü ise erkek öğrencilerden oluşmuştur. Katılımcılarla ilgili demografik özelliklere ilişkin bulgular Tablo 1'de sunulmaktadır.

Tablo 1: Demografik Özellikler

\begin{tabular}{|c|c|c|c|c|c|}
\hline Cinsiyet & Sıklık & $\%$ & Yaşadığınız Yer & Sıklık & $\%$ \\
\hline Kadın & 162 & 53,1 & Kentsel & 202 & 66,2 \\
\hline Erkek & 143 & 46,9 & Kırsal & 103 & 33,8 \\
\hline Toplam & 305 & 100 & Toplam & 305 & 100,0 \\
\hline Yetiştirilme Tarzı & Sıklık & $\%$ & Ortalama Gelir & Sıklık & $\%$ \\
\hline Baskıcı & 51 & 16,7 & 1400 ve daha az & 57 & 18,6 \\
\hline Kontrollü & 168 & 55,1 & $1400-3000$ & 118 & 38 \\
\hline Serbest & 86 & 28,2 & 3001 ve 4500 & 84 & 27,5 \\
\hline Toplam & 305 & 100,0 & 4501 ve üzeri & 46 & 15,9 \\
\hline & & & Toplam & 305 & 100,0 \\
\hline Ailede Girişimci Var Mı? & Sıklık & $\%$ & Okudukları Bölüm & Sıklık & $\%$ \\
\hline Evet & 104 & 34,1 & Sosyal & 218 & 71,4 \\
\hline Hayır & 201 & 65,9 & Teknik & 87 & 28,6 \\
\hline Toplam & 305 & 100,0 & Toplam & 305 & 100,0 \\
\hline
\end{tabular}

Demografik özelliklerin verildiği tabloda Cinsiyet, Yaşadığı Yer, Yetiştirilme Tarzı, Ailede daha önce kendi işini yapmış olan var mı?, ortalama gelir ve okudukları bölüm soruları sorulmuştur. Önlisans 2 . Sınıf öğrencilerine anket uygulandığı için ve bu grubun belli bir yaş aralığında olmasından dolayı katılımcılara yaş sorusu sorulmamıştır. Araştırmaya katılanların cinsiyet dağııımı incelendiğinde \%53,1'i kadın, \%46,9'u ise erkeklerden oluşmaktadır. Dengeli bir dağılımın olduğunu söylemek mümkündür. Yaşadıkları yer açısından ise katılımcıların \%66'sı şehir merkezlerinde yaşadığını ifade etmektedir. Yetiştirilme tarzı açısından ise katılımcıların \%55'i kontrollü bir aileden geldiklerini ifade etmişlerdir. "Ailede girişimci var mı?” sorusuna ise \%34'ü evet \% 66'sı ise hayır cevabı vermişlerdir. Ortalama gelir açısından ise katılımcıların 1400 TL ile 4500 TL arasında gelire sahip oldukları ifade edilmiştir. Katılımcıların \%71,4'ünün sosyal bölümlerden, \%28,6'sı ise teknik bölümlerden oluşmaktadır.

Araştırmada, bağımlı değişken olarak ele alınan girişimcilik potansiyeli ile bağımsız değişken olarak ele alınan sosyal zekâ düzeyleri arasındaki bağıntıyı ortaya koyma amaçlanmaktadır. Yukarıda da belirtildiği gibi girişimcilik potansiyeline yönelik sorular Ören ve Biçkes (2011)'den yararlanılarak oluşturulmuş ve sosyal zekâ için de Tromso Sosyal Zeka Ölçeği (TSZÖ) kullanılmıştır. Elde edilen veriler istatistiki bir program yardımı ile değerlendirmeye tabi tutulmuştur.

Yapılan çalışmada elde edilen verilerin normal dağılıma uyup uymadığı hipotezlerin testi açısından önem taşımaktadır. Bu uygunluk için Kolmogorov-Smirnov testi yapılmıştır. Her iki değişkeninde bu test sonucunda normal dağılıma uygun olduğu sonucuna varılmıştır. Yapılacak olan korelasyon ve regresyon analizleri bu sayede sağılıkı sonuçlar verebileceği düşünülmektedir.

Değişkenler arasındaki ilişkilerin büyüklüğünü, yönünü ve önemini açıklamak amacıyla korelasyon analizi yapılmıştır. Elde edilen sonuçlar Tablo 2'de gösterilmektedir. Korelasyon katsayısı \% 0 ise ilişki olmadığı, 01-20 arasında ise ilişki çok zayıf, 2150 arasında ise zayıf ilişki 51-70 arasında nispeten güçlü 71-90 arasında ise güçlü ilişki ve 91-100 arasında ise çok güçlü ilişki olduğu anlamına gelmektedir (Nakip, 2003: 322). Korelasyon analizi için sosyal zekânın üç alt boyutu ile girişimcilik potansiyeli arasındaki ilişki Tablo 2'de incelenmektedir. 
Tablo 2: Sosyal Zekâ düzeyleri ile Girişimcilik Potansiyeli Arasındaki iliş̧ki

\begin{tabular}{|l|c|c|c|c|c|}
\hline & $\begin{array}{c}\text { Sosyal Bilgi } \\
\text { Süreci }\end{array}$ & $\begin{array}{c}\text { Sosyal } \\
\text { Farkındalık }\end{array}$ & Sosyal Beceri & Sosyal Zekâ & Girişimcilik \\
Sosyal Bilgi Süreci & 1 & $320^{* *}$ & 1 & & \\
Sosyal Farkındalık &, $480^{* *}$ &, $410^{* *}$ & 1 & \\
Sosyal Zekâ &, $510^{* *}$ &, $542^{* *}$ &, $531^{* *}$ &, $418^{* *}$ & 1 \\
Girişimcilik &, $385^{* *}$ &, $410^{* *}$ &, $518^{* *}$ & 1 \\
$* *$. Correlation is significant at the 0.01 level (2-tailed). & & & \\
\hline
\end{tabular}

Tablo 2'de görüldüğü üzere yapılan korelasyon analizinde sosyal zekanın alt boyutları ile girişimcilik potansiyelleri arasında p<0,01 anlamlılık düzeyinde ilişkiler saptanmıştır. Tablo 2'deki bulgulara göre, öğrencilerin girişimcilik potansiyelleri ile sosyal bilgi süreci boyutu arasında pozitif yönde anlamlı bir ilişki $(r=0,385)$ tespit edilmiştir.

Sosyal zekâ boyutları arasından sosyal farkındalık ile girişimcilik potansiyeli arasında ise pozitif yönlü anlamlı bir başka ilişki $(r=0,410)$ bulunmaktadır. Sosyal beceri boyutu ile girişimcilik boyutu arasında ise pozitif yönlü ve diğerlerine göre nispeten daha güçlü $(r=0,418)$ iliş̧i elde edilmiştir.

Genel sosyal zekâ ölçeğinin doğrudan girişimcilik potansiyeli ile olan ilişkisine baktığımızda pozitif yönlü nispeten güçlü $(r=0,518)$ bir ilişkinin olduğunu görmekteyiz. Sosyal zekâ değişkenlerine genel olarak bakıldığında girişimcilik potansiyeli ile pozitif yönlü ilişki içerisinde olduğu görülmektedir. Bu sonuçlara göre $\mathrm{H} 1$ ve H2 hipotezlerimiz kabul edilmektedir. Bu sonuca göre araştırma yapılan öğrenciler üzerinde sosyal zekâ seviyeleri ile girişimcilik potansiyeli arasında pozitif yönde ilişkinin olduğu ve buna bağıı olarak sosyal zekâsı artan bireyin girişimcilik kabiliyetinin de arttığını ifade etmek mümkündür.

Çalışmada bağımlı ve bağımsız değişkenler arasında ilişkiyi incelemek için kullanılan diğer bir yöntem ise regresyon analizidir. Regresyon, bir bağımlı değişken ile bir veya daha fazla sayıda bağımsız değişken arasındaki ilişkiyi incelemek amacıyla kullanılan istatistiki bir yöntemdir (Altunışık vd. 2005: 233). Sosyal zekânın bağımlı, girişimcilik potansiyelinin bağımsız değişken olarak ele alındığı Tablo 3'e bakıldığında araştırmada yer alan bağımsız değişkenin standart Beta katsayıları ile $\mathrm{t}$ ve $\mathrm{p}$ değerleri verilmiştir. Kurulan regresyon modelin istatistiksel olarak anlamlı olduğu tespit edilmiştir ( $\mathrm{F}=$ $46,300 ; p<0.05)$.

Tablo 2: Sosyal Zekâ düzeylerinin Girişimcilik Potansiyeline etkisi

\begin{tabular}{|c|c|c|c|c|c|}
\hline \multirow[b]{2}{*}{ Model } & \multicolumn{2}{|l|}{$\begin{array}{l}R^{2}=0,627 \\
F=46,300\end{array}$} & \multicolumn{3}{|c|}{$\begin{array}{l}\text { Ayarlanmış } R^{2}=0,480 \\
P \text { değeri }=, 000\end{array}$} \\
\hline & B & Std. Hata & Beta & $\mathrm{t}$ & P. Değeri \\
\hline Sabit &,- 457 & ,348 & & $-1,467$ & ,094 \\
\hline Sosyal bilgi süreci & ,322 & 121 & ,305 & 2,146 & 009 \\
\hline Sosyal farkındalık & 156 & 142 & 109 & 1,426 & 019 \\
\hline Sosyal beceri & ,186 & ,201 & ,298 & 2,299 & 014 \\
\hline \multicolumn{6}{|c|}{ Bağımlı Değişken: Girişimcilik potansiyeli } \\
\hline
\end{tabular}

Sosyal zekâ düzeylerinin girişimcilik potansiyeli üzerindeki etkisinin araştırıldığı modelde bağımsız değişkenlerin bağımlı değişkenleri açıklama oranı için ayarlanmış $\mathrm{R}^{2}$ değeri 0,480 olarak bulunmuştur. Bağımsız değişkenlerden sosyal bilgi süreci için $\beta=.305, p=.000$ değerine, sosyal farkındalık için $\beta=.109, p=.001$, sosyal beceri için $\beta=.298, p=.000$, değerlerine ulaşılmıştır. Bu sonuçlara göre sosyal zekâ boyutlarının girişimcilik potansiyelini pozitif yönde etkilediği ve bu etkinin istatistiki olarak güçlü anlamlılığa sahip olduğu görülmektedir. Bu sonuçlar çerçevesinde değerlendirildiğinde oluşturulmuş olan her iki hipotezimiz de kabul edilmiştir.

\section{SONUÇ}

Girişimciliğin ülke ekonomisi ve kalkınmasında önemli bir rolünün olması ve ehemmiyetinin daha fazla anlaşılmasının ardından girişimci çıkartma heyecanı doğmuş, devlet ise bunun için çeşitli politikalar, yasal düzenlemeler, hibe ve teşvikler hazırlamıştır. Girişimcilik için uygun zeminin hazırlanması kadar uygun girişimci profilinin de olması başarıyı etkileyen en önemli unsurların başında gelmektedir. Özellikle girişimci olacak kişinin tabir yerinde ise "leb demeden leblebiyi anlayacak" düzeyde olması yeni başlayacağı iş kolunda başarıya ulaşmasını kolaylaştıracaktır. Özellikle söylenmeyenlerin ardındaki 
gerçeği anlayabilen, beden dili okuyabilen yani sosyal zekâsı yüksek kişilerin girişimci olma ve devam etme becerilerinin yüksek oalcağı düşünülmektedir. Bundan dolayı bu çalışmada, üniversitelerde eğitim gören öğrencilerin girişimcilik potansiyeli ile sosyal zekâ ve sosyal zekâ alt boyutlarının girişimcilik potansiyeli arasındaki ilişkiyi ortaya çıkartılmıştır. Araştırmada Dumlupınar Üniversitesine bağlı meslek yüksekokulları öğrencilerinin sosyal zekâ düzeyleri dikkate alınarak girişimcilik potansiyelleri ölçülmeye çalışımıştır. Sosyal zekâ ve sosyal zekânın alt boyutları olan sosyal bilgi süreci, sosyal farkındalık ve sosyal beceri düzeyleri arasında bir farklılık olup olmadığı incelenmiştir. Meslek yüksekokulu öğrencilerinin sosyal zekâ seviyeleri ile girişimcilik potansiyelleri arasında pozitif bir ilişki olduğu görülmektedir. Bu açıdan bakıldığında bir bireyin sosyal zekâsının gelişimi ne kadar çok desteklenirse girişimcilik potansiyelinin de o denli artacağı ifade etmek mümkündür.

Yapılan çalışmada demografik değişkenlerden cinsiyetle ilgili herhangi bir analiz yapılmamıştır. Literatür tarandığında çeşitli çalışmalarda kız ve erkek arasında anlamlı farklılıkların bulunmadığı sonucuna varılmıştır (Balat ve Akman, 2004; Baybek ve Yavuz, 2005; Doğan, 2006; Çevik ve Atıcı, 2009; Razı ve ark., 2009). Doğan vd., (2009) yapmış oldukları çalışmada ise üniversite öğrencilerinin okudukları bölümler arasında sosyal zeka alt boyutları açısından herhangi bir farklılık göstermediği sonucuna ulaşmıştır.

Yapılan korelasyon analizi sonuçlarına göre sosyal zeka düzeyleri ile girişimcilik potansiyelleri arasında pozitif yönlü $(r=0,518)$ anlamlı bir ilişki olduğu görülmektedir. Korelasyon analizi sonucuna bakıldığında, sosyal zekâ düzeylerinin sosyal bilgi süreci, sosyal farkındalık ve sosyal beceri boyutları ile girişimcilik potansiyelleri arasında pozitif yönde anlamlı ilişkinin olduğu bulunmuştur. Sosyal zekâsı yüksek olan kişilerin özellikle sosyal zekâsının performans boyutu olan sosyal beceri konusunda kendilerine güvenlerinin yüksek olduğu, insan ilişkileri konusunda daha girişken oldukları (Doğan, 2006) dikkate alınırsa yapılmış olan çalışmanın sonuçlarının literatüre uygun sonuçlar verdiğini söylemek mümkündür. Regresyon analizi sonuçlarına göre sosyal zekâ düzeyleri, girişimcilik potansiyellerini \%48'lik bir oranda etkilemektedir. Sosyal zekâ düzeylerinin girişimcilik potansiyelini pozitif yönde etkilediği ve bu etkinin istatistiki olarak güçlü anlamlılığa sahip olduğu tespit edilmiştir. Bu sonuçlara göre sosyal farkındalık, sosyal bilgi süreci ve sosyal becerisi yüksek kişilerin girişimci olmada etkili olduğu sonucuna ulaşılmıştır.

Bu alanda yapılan farklı araştırmalarda da yapıımış olan bu çalışmaya benzer sonuçların çıktığını ifade etmek mümkündür. Parlak (2013)'ün çalışmasında, kendini ve başkalarını tanıma becerisi (içsel ve sosyal zekâ) ile girişimci kişilik özellikleri arasında pozitif ve anlamlı bir ilişkinin var olduğu ifade etmiştir. Yine bu çalışmada sosyal zekânın alt boyutları ile incelenmesinin girişimcilik üzerinde hangi boyutun daha fazla etkiye sahip olacağı yönünde fikir vereceğini ifade etmiş böyle bir çalışmanın gerekliliğine vurgu yapmıştır. Demirel vd. (2011) girişimci olabilmiş insanların çoklu zekaya dayalı yeteneklerinin girişimcilik düşünceleri üzerinde anlamlı bir belirleyici etkisi olduğunu ifade etmiştir. Çoklu zekâ alanları girişimcilik düşünceleri üzerinde yaklaşık \%40 civarında belirleyici etkiye sahip denilmiştir. Bu sonucun araştırmamıza yakın bir değer olması sebebiyle literatüre uygunluğu ifade edilebilir. Bunların yanında girişimcilik farklı zekâ türleri ile olan ilişkisini inceleyen çalışmalarda Polat ve Aktop (2010)'un duygusal zekâ alt boyutlarının girişimcilik davranışı üzerinde etkili olduğu sonucuna ulaşmışlardır. Doğan vd. (2009) yapmış olduğu çalışmada sosyal zekâ düzeyleri arttıkça benlik saygısı seviyesinin de arttığını ifade etmektedir. Yine sosyal zekâ boyutlarından sosyal becerinin yüksek olduğu bireylerde insan ilişkilerinde daha girişken oldukları ifade edilmiştir (Doğan,2006). İnsan ilişkileri yüksek olan bireylerin ise girişimci olma yönünde daha fazla istekli oldukları söylenebilir (Uluköy vd., 2016).

Araştırma sonucunda elde edilen bulgulara göre sosyal zekâ alt boyutları olan sosyal bilgi süreci, sosyal farkındalık ve sosyal beceri, girişimcilik potansiyelini olumlu yönde etkilemektedir. Sonuç olarak sosyal zekâ ve sosyal zekâ alt boyutlarına sahip bireylerin daha fazla girişimcilik potansiyeline sahip olduğu sonucuna ulaşmak mümkündür.

\section{KAYNAKLAR}

Altan, M. Z. (2011). Çoklu Zekâ Kuramı ve Değerler Eğitimi. Pegem Eğitim ve Öğretim Dergisi, 1,(4), 53-57.

Altunışık, Remzi; Coşkun, Recai, Bayraktaroğlu, Serkan ve Yıldırım, Engin, (2005), Sosyal Bilimlerde Araştırma Yöntemleri SPSS Uygulamalı, Dördüncü Baskı, Sakarya Kitabevi, Adapazarı.

Armstrong, T. (1994). Multiple Intelligences In The Classroom. Alexandria, VA: Association for Supervision and Curriculum Dev elopment.

Ayaydın, A. (2004). Sana Eğitiminde Çoklu Zeka Yöntemi ve Uygulama Örneği. Pamukklae Eğitim Fakültesi Dergisi, 15, 18-30.

Baş, G. (2011). Çoklu Zekâ Kuramının Öğrenme-Öğretme Süreçlerine Yansıması. Bilim ve Aklın Aydınlığında Eğitim, S. 138-139, ss.14-28.

Baybek, H. VE Yavuz S. (2005). Muğla Üniversitesi öğrencilerinin benlik saygılarının incelenmesi. Muğla Üniversitesi Sosyal Bilimler Enstitüsü Dergisi, 14, 73-95.

Bellanca, J. (1997). Active Learning Handbook for Multiple Intelligence Classrooms. USA: IRI/Skylight Training and Publishing Inc.,

Bozkurt, Ö. Ç., Kalkan, A., Koyuncu, O. ve Alparslan A. M. (2012). Türkiye'de Girişimciliğin Gelişimi: Girişimciler Üzerine Nitel Bir Araştırma. Süleyman Demirel Üniversitesi Sosyal Bilimler Enstitüsü Dergisi, 15, 229-247. 
Crowne, K. A., (2007). The Relationships Among Social Intelligence, Emotional Intelligence, Cultural Intelligence and Cultural Exposure. Temple University: USA.

Çakır, i. (2004). Eğitimde Yeni Bir Yaklaşım: Çoklu Zekâ Kuramı. Eğitimbilim, Sayı 73.

Çevik G. B. VE Atıcı, M. (2009). Lise 3. sınıf öğrencilerinin benlik saygılarının bazı değişkenler açısından incelenmesi. Uluslararası İnsan Bilimleri Dergisi. 6 (1).

Demirel, E. T., Düşükcan, M. ve Ölmez, M. (2011). Çoklu Zekâ Alanlarının Girişimcilik Davranışına Etkisi. Organizasyon ve Yön etim Dergisi, 3(2), 97-105.

Doğan, S. ve Demiral, Ö. (2007). Kurumların Başarııında Duygusal Zekanın Rolü ve Önemi. Celal Bayar Üniversitesi İktisadi ve İdari Bilimler Fakültesi, Yönetim ve Ekonomi Dergisi; 14 (1), 209-230.

Doğan, T. ve Çetin, B. (2009). Tromso Sosyal Zekâ Ölçeği Türkçe Formunun Faktör Yapısı, Geçerlik ve Güvenilirlik Çalışması. Kuram ve Uygulamada Eğitim Bilimleri Dergisi, 9 (2), 691-720.

Döm, S. (2006). Girişimcilik ve Küçük İşletme Yöneticiliği. Detay Yayımcılık: Ankara.

Gardner, H. (1993a). Frames of Mind: The Theory of Multiple Intelligences. (Second Edition). London: Falmer Press.

Gardner, H. (1993b). Multiple Intelligences: Theory in Practice. New York: Basic Books.

Gardner, H. (1999). Intelligences Reframed: Multiple Intelligences for the 21st Century. New York: Basic Books.

Goleman, D. (2014). Duygusal Zeka Neden IQ'dan Daha Önemlidir? (39. Baskı). Varlık Yayınları, Ankara.

Hisrich, R.D., Peters, M.P. (2002). Entrepreneurship. McGraw-Hill HigherEducation.

İlhan, S. (2003). Sosyo-Ekonomik Bir Fenomen Olarak Girişimciliğin Oluşumunu Etkileyen Başlıca Faktörler. Muğla Üniversitesi, SBE Dergisi, 11, 61-79.

Kozak, M. A. ve Yılmaz, E. G. (2010). Otel Yöneticilerinin İç Girişimcilik Algılamaları: Frigya Bölgesi Örneği. Anatolia: Turizm Araştırmaları Dergisi, 21 (1), 85-97.

Marecki, J. (2014). The Importance of Social Intelligence for Entrepreneurial Leaders. http://essay.utwente.nl/65265/ (12.04.2017).

Marlowe, H. (1986).Social Intelligence: Evidence for Multidimensionality and Gonstruct Indepence. Journal oj Educational Psychology. 78 (1), 52-58.

Nakip, M., (2003), Pazarlama Araştırmaları Teknikler ve SPSS Destekli Uygulamalar, Seçkin Yayınları, Birinci Baskı, Ankara.

Parlak, K. (2013), “Girişimci Kişilik Özelliklerine Sahip Olmak İle Kendini ve Başkalarını Tanıma (įçsel ve Sosyal) Zekaları Arasındaki ilişsinin Incelenmesi", İstanbul Sabahattin Zaim Üniversitesi Sosyal Bilimler Dergisi, 3: 55-64.

Öner, N. (1997). Türkiye'de Kullanılan Psikolojik Testler. Boğaziçi Üniversitesi Matbaası: İstanbul.

Ören, K. ve Biçkes M. (2011). Kişilik Özelliklerinin Girişimcilik Potansiyeli Üzerindeki Etkileri (Nevşehir'deki Yüksek Öğrenim Öğrencileri Üzerinde Yapılan Bir Araştırma). Süleyman Demirel Üniversitesi îktisadi ve İdari Bilimler Dergisi, 16(3), 67-86.

Özgener, Ş. (2003). Girişimcilikte Stratejik Bir Yaklaşım: Teknoloji İnkübatörleri, 11. Ulusal Yönetim ve Organizasyon Kongresi Bildiriler Kitabı: Afyonkarahisar.

Razi, G. S. , Kuzu, A. , Yildiz, A. N. , Ocakçi, A. F. VE Arifoğlu, B. Ç. (2009). Çalışan gençlerde benlik saygısı, iletişim becerileri ve stresle baş etme. Türk Silahlı Kuvvetleri, Koruyucu Hekimlik Dergisi, , 8(1), 17-26.

Saban, A. (2001). Çoklu Zeka Teorisi Ve Eğitim. Nobel Yayın Dağııım: Ankara.

Saban, A. (2004). Çoklu Zekâ Teorisi ve Eğitim. (Dördüncü Baskı). Ankara: Nobel Yayın Dağııım.

Sabuncuoğlu Z. ve Tokol, T. (2013). Genel işletme (2. Baskı). Bata Basım: İstanbul.

Silvera, D. H., Martinussen, M., ve Dahl, T. I. (2001). The Tromso Social Intelligence Scale, A Self-Report Measure of Social Intelligence, Scandinavian Journal of Psychology, 42, 313-331.

Saylan, G. (1974). Türkiye'de Kapitalizm Bürokrasi ve Siyasal İdeoloji, Türkiye ve Orta Doğu Amme Idaresi Enstitüsü Yayınları, No. 140 Ankara.

Tutar, H. (2013). İ̧̧letme Yönetimi (Geliştirilmiş ve Gözden Geçirilmiş 5. Baskı). Seçkin Yayıncılık: Ankara.

Uluköy, M., Ülker, Y., Kılıç, R., Yumuşak, S., Azaklı, S. (2016). Duygusal Zekânin Girişimcilik Üzerine Etkisi: Küçük Ve Orta Ölçekli Işsletmeler Üzerine Bir Analiz, MANAS Sosyal Araştırmalar Dergisi, Vol.: 5 No: 5.

Vural B. (2004). Öğrenci Merkezli Eğitim ve Çoklu Zekâ. Hayat Yayınları: İstanbul.

Yılmaz A. (2008). Sosyal Bilgiler Dersi Tarih Konularıın Çoklu Zekâ Kuramın Göre işlenişi, Marmara Coğrafya Dergisi, 18, 238-252. 